\title{
Seasonal dynamics and decadal changes of benthic foraminiferal assemblages in the western Baltic Sea (NW Europe)
}

\author{
JOACHIM SCHÖNFELD ${ }^{1} \&$ LEA NUMBERGER ${ }^{2}$ \\ ${ }^{1}$ IFM-GEOMAR, Wischhofstrasse 1-3, D-24148 Kiel, Germany (e-mail: jschoenfeld@ifm-geomar) \\ ${ }^{2}$ Institut für Geologie und Paläontologie der Universität Tübingen, Sigwartstrasse 10, D-72076 Tübingen, Germany
}

\begin{abstract}
Living benthic foraminiferal assemblages were monitored between January and July 2004 in the Kiel Bight, Baltic Sea. Phytoplankton blooms and the deposition of organic detritus were depicted by fluorometer hydro casts and pigment concentrations in surface sediments. Three depositional pulses of organic matter were identified by high phytoplankton concentrations above the sea floor and elevated pigment concentrations in the surface sediment. The foraminiferal assemblage composition remained rather constant but the population density of Elphidium excavatum clavatum showed a two- to six-fold increase within a few days after organic detritus deposition. The foraminiferal assemblage composition was compared to earlier studies in this area. Elphidium excavatum, Ammotium cassis and E. incertum dominated the living fauna in the 1960s and 1970s. The recent survey revealed a predominance of $E$. excavatum subspecies (more than $90 \%$ of the living assemblage). The average population densities were six times higher than in the 1970s. Data structure and model calculations suggested that E. excavatum clavatum is able to reproduce rapidly, with high offspring numbers at elevated food supply. The diminution of $A$. cassis has occurred in Kiel Bight during the last ten years and was most likely induced by a period of low deep-water salinities in the early 1990s. J. Micropalaeontol. 26(1): 47-60, April 2007.
\end{abstract}

KEYWORDS: foraminifera, assemblages, phytoplankton, environmental change, Baltic Sea

\section{INTRODUCTION}

Benthic foraminifera from the western Baltic Sea have been studied intensively since the pioneering work of Rhumbler (1935). These studies have focused on taxonomy and ecology (Van Voorthuysen, 1960; Lutze, 1965; Haake, 1967), revealed basin-wide distribution patterns (Rottgardt, 1952; Brodniewicz, 1965; Hermelin, 1987), aspects of carbonate production and preservation (Wefer \& Lutze, 1978) and benthic foraminiferal biomass (Altenbach, 1985). A few studies have also focused on monitoring the small-scale and short-term faunal dynamics (Lutze, 1968a, b; Wefer, 1976). A comprehensive overview of the results from the 1960s and 1970s, depicting the principal faunal distribution in their environmental context, was presented by Lutze (1974) and Lutze et al. (1983). They found that water turbulence and hydrographical boundary layers exert a major control on both surface sediment composition and benthic foraminiferal assemblages. Substrate properties, such as the presence of macrophytic algae and large pebbles, facilitate the recruitment of specialized epibenthic species, called 'Phytalfauna'. In general, foraminifera are considered an important constituent of the benthic ecosystem in the Baltic Sea. The benthic foraminiferal biomass is estimated at 30\% to $200 \%$ of the meiofauna, and food consumption by benthic foraminifera amounts to between $5 \%$ and $15 \%$ of the total annual flux of particulate organic matter (Altenbach, 1985). The biogenic carbonate production is in the same order of magnitude as in other marginal seas, but $40-70 \%$ of benthic foraminiferal tests from the dead foraminiferal assemblage are immediately dissolved after deposition (Wefer, 1976).

Despite occasional sampling in places, no comprehensive benthic foraminiferal studies in the western Baltic Sea were undertaken in the 1980s and 1990s. However, the lagoons ('Botten') of the southern Baltic Sea were investigated (Kreisel \&
Leipe, 1989; Frenzel, 1996; Frenzel \& Oertl, 2002). The marine environment experienced a dramatic increase in nutrient supply from agricultural and domestic sewage inflow which led to a series of strong algal blooms and oxygen crises in the deep basins in the 1980s. The setup of central, biological clarification plants and a restrictive surface-water protection legacy in Germany and Denmark (e.g. the Danish Action Plan (I) on the Aquatic Environment from 1987) led, together with a decrease in industrial and agricultural production in eastern Germany in the 1990s, to a halt and slight decrease in nutrient levels and to a stabilization of the ecosystems (Nehring, 1991; Nausch et al., 2004). The oxygen budget of the deep waters was also replenished by a series of saltwater influxes from the Kattegat in 1993/1994 and in January 2003 (e.g. Nordberg et al., 2001; Feistel et al., 2003; Nausch et al., 2003).

Studies on the decadal and long-term dynamics of foraminiferal assemblages in conjunction with environmental monitoring are rare (Murray, 2000). A considerable number of such investigations focused on the Skagerak and Kattegat region to the north of the western Baltic Sea (Moodley et al., 1993; Alve \& Murray, 1995; Alve, 1996; Gustafsson \& Nordberg, 2001). The faunal changes were either linked to progressive environmental changes during the past decades, in particular to eutrophication and increased storm frequency in the Kattegat (Seidenkrantz, 1993; Christiansen et al., 1996), or they were related to recurrent anoxia and flushing of fjord basins at the western Swedish coast (Filipsson \& Nordberg, 2004a, b) driven by changes in the North Atlantic Oscillation (NAO) (Hurrell, 1995).

The aim of this study is to investigate whether similar, decadal changes in benthic foraminiferal assemblages are recognizable in the western Baltic Sea. A comparable faunal response to natural climate variability or anthropogenic environmental change may be anticipated because of the isolated setting of this 


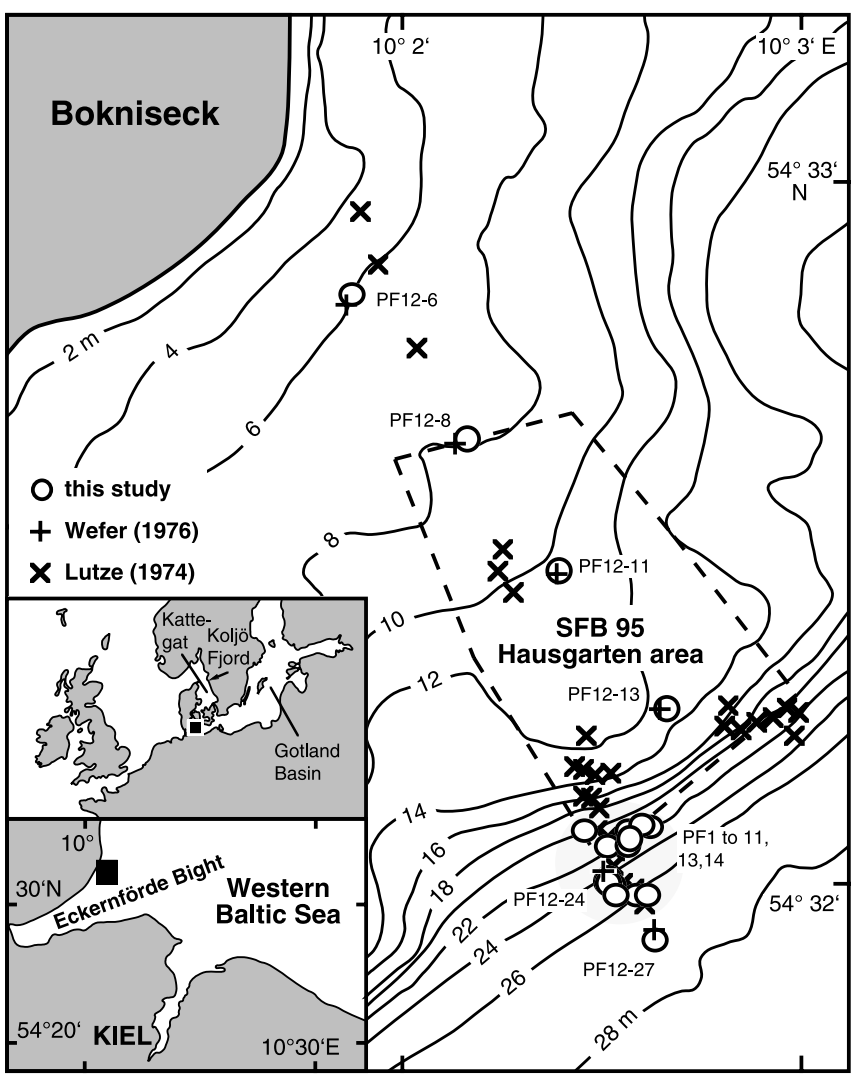

Fig. 1. Location of surface samples in the 'Hausgarten' area off Bokniseck in the western Baltic Sea considered in the present study. The light grey patch marks the monitoring site at $23.5 \mathrm{~m}$ water depth. Samples of Lutze (1965) as considered in Figs 7 and 8 were also taken on the northeastern flank of Eckenförde Bight close to the Hausgarten area.

marginal sea. Another objective is to describe seasonal changes in benthic foraminiferal community structure and population density and to compare them to the faunal dynamics in the 1970s.

\section{GEOLOGICAL AND HYDROGRAPHICAL SETTING}

The central study area ('Hausgarten') of the former Special Research Unit ('Sonderforschungsbereich, SFB') 95 at Kiel University is situated off Bokniseck at $54^{\circ} 2^{\prime} \mathrm{N}$ and $10^{\circ} 02^{\prime} \mathrm{E}$ (Fig. 1). The 'Hausgarten' is on the outer, northwestern margin of the Eckernförde Bight, which is a shallow fjord-type embayment of the Kiel Bight in the western Baltic Sea. The study area comprises a depth transect of $0.7 \mathrm{~km}$ width and $1.2 \mathrm{~km}$ length, ranging from $5 \mathrm{~m}$ to $29 \mathrm{~m}$ water depth. The upper part of the transect forms a shallow ramp that commences at the shore and ranges to $13 \mathrm{~m}$ water depth. The bottom sediment is a thin veneer of coarse sand with pebbles, covering bedrock of Late Pleistocene till. This cover may form a boulder pavement in places. The slope steepens at $13 \mathrm{~m}$ and the bottom sediment passes into a medium to fine sand. The sand content and grain size further decrease with depth into sandy mud at $23 \mathrm{~m}$, which covers the floor of the entire deep basin. The main source of terrigenous sediment is coastal and seabed erosion at the cliffs and on the shoal (Flemming \& Wefer, 1973).
The hydrography is characterized by a Surface Water of low salinities (14-19 units in 1964-1974) and a higher-saline Kattegat Water below (20-24 units in 1964-1974) (Rheinheimer, 1996). The boundary layer separating these water masses was centred around $20 \mathrm{~m}(16-23 \mathrm{~m})$ water depth in the 1970s (Lenz, 1974). In 2004, the boundary layer was slightly higher at $16-18 \mathrm{~m}$. The salinity ranges of both Surface and Kattegat Water were slightly lower in 2004 (respectively 10-19 and 17-21 units) than in the $1970 \mathrm{~s}$.

The primary production is characterized by a strong spring bloom in March and April, when Bacillariophycean diatoms are the main producers (Rheinheimer, 1996). The spring bloom is followed by several smaller summer blooms from June to September and a small autumn bloom in October and November (Bodungen, 1975; Hällfors \& Niemi, 1986). The primary production was estimated to be $158 \mathrm{~g} \mathrm{C} \mathrm{m}^{-2} \mathrm{a}^{-1}$ in 1973. Enhanced nutrient influx and recycling induced a substantial eutrophication of the Baltic Sea during the 1970s and 1980s which led to an annual increase in primary production of between $5 \mathrm{~g} \mathrm{C} \mathrm{m}^{-2} \mathrm{a}^{-1}$ and $10 \mathrm{~g} \mathrm{C} \mathrm{m}^{-2} \mathrm{a}^{-1}$ in consecutive years (Kaczmarek et al., 1997). For instance, a total increase of $63 \mathrm{~g} \mathrm{C} \mathrm{m}^{-2} \mathrm{a}^{-1}$ was estimated for the period 1966-1990 for the Belt Sea (Wassmann, 1990). Not less than $61 \%$ of the organic detritus produced by the phytoplankton in the Surface Water is deposited in the deep basins (Bröckel, 1975; Wefer, 1976; Altenbach, 1985). The decomposition of the organic material may lead to strong oxygen consumption and even suboxic conditions in the deep basins of the western Baltic Sea during summer (Fonselius, 1962).

\section{MATERIAL AND METHODS}

Surface sediment samples were taken from the 'Hausgarten' area of the former SFB 95 off Bokniseck on 14 daily cruises with $R / V$ Polarfuchs from January to July 2004 (Fig. 1, Table 1). The study also considered two surface samples taken in the outer Kiel Fjord with $R / V$ Poseidon in 1996. Furthermore, it considered faunal information provided by Peter Linke, Kiel, from three surface samples he took on scuba dives at $10 \mathrm{~m}, 14 \mathrm{~m}$ and $18 \mathrm{~m}$ water depth in the 'Hausgarten' area in April 1985. On the $R / V$ Polarfuchs, a Van Veen grab of $250 \mathrm{~cm}^{2}$ surface area was used (Stations PF12-8 to PF12-27), and a Rumohr corer with a tube of $56 \mathrm{~mm}$ inner diameter at the $23.5 \mathrm{~m}$ monitoring site (Stations PF1 to PF11, PF13 and PF14). In order to minimize the bias by patchiness in foraminiferal distribution, the Rumohr corer was always deployed three times and the uppermost centimetre of the sediment was removed on each deployment with a spoon. The sediment was placed in a PVC vial and mixed carefully. Subsamples for pigment analyses were taken from this blend first. The remaining sample was then preserved and stained with a solution of $2 \mathrm{~g}$ rose Bengal per litre ethanol in order to later identify foraminifers living at the time of sampling as stained tests (Lutze \& Altenbach, 1991; Murray \& Bowser, 2000).

The samples were left in a cold store for at least two weeks after the cruise in order to facilitate complete staining. The samples were first passed through a $2000 \mu \mathrm{m}$ screen in order to remove pebbles and other large particles that would grind fragile tests and then gently washed through a $63 \mu \mathrm{m}$ sieve. The size fractions $>2000 \mu \mathrm{m}$ and $63-2000 \mu \mathrm{m}$ were dried at $60^{\circ} \mathrm{C}$ and 


\begin{tabular}{lrcrr}
\hline Station & Date & $\begin{array}{c}\text { Longitude } \\
\left({ }^{\circ} \mathrm{E}\right)\end{array}$ & $\begin{array}{c}\text { Latitude } \\
\left({ }^{\circ} \mathrm{N}\right)\end{array}$ & $\begin{array}{c}\text { Depth } \\
(\mathrm{m})\end{array}$ \\
\hline Monitoring site & & & & \\
PF1 & 30.01 .2004 & $10^{\circ} 2.502^{\prime}$ & $54^{\circ} 32.022^{\prime}$ & 23.5 \\
PF2 & 13.02 .2004 & $10^{\circ} 2.508^{\prime}$ & $54^{\circ} 32.026^{\prime}$ & 23.5 \\
PF3 & 17.02 .2004 & $10^{\circ} 2.613^{\prime}$ & $54^{\circ} 32.098^{\prime}$ & 23.5 \\
PF4 & 20.02 .2004 & $10^{\circ} 2.519^{\prime}$ & $54^{\circ} 32.016^{\prime}$ & 23.5 \\
PF5 & 24.02 .2004 & $10^{\circ} 2.506^{\prime}$ & $54^{\circ} 32.071^{\prime}$ & 23.5 \\
PF6 & 26.02 .2004 & $10^{\circ} 2.447^{\prime}$ & $54^{\circ} 32.092^{\prime}$ & 23.5 \\
PF7 & 02.03 .2004 & $10^{\circ} 2.556^{\prime}$ & $54^{\circ} 32.092^{\prime}$ & 23.5 \\
PF8 & 04.03 .2004 & $10^{\circ} 2.592^{\prime}$ & $54^{\circ} 32.100^{\prime}$ & 23.5 \\
PF9 & 11.03 .2004 & $10^{\circ} 2.578^{\prime}$ & $54^{\circ} 32.003^{\prime}$ & 23.5 \\
PF10 & 05.04 .2004 & $10^{\circ} 2.556^{\prime}$ & $54^{\circ} 32.072^{\prime}$ & 23.5 \\
PF11 & 06.05 .7004 & $10^{\circ} 2.561^{\prime}$ & $54^{\circ} 32.082^{\prime}$ & 23.5 \\
PF13 & 30.06 .2004 & $10^{\circ} 2.527^{\prime}$ & $54^{\circ} 32.003^{\prime}$ & 23.5 \\
PF14 & 15.07 .2004 & $10^{\circ} 2.605^{\prime}$ & $54^{\circ} 32.003^{\prime}$ & 23.5 \\
& & & & \\
Additional sampling stations & & & \\
PF12-6 & 19.05 .2004 & $10^{\circ} 1.871^{\prime}$ & $54^{\circ} 32.834^{\prime}$ & 6.0 \\
PF12-8 & 19.05 .2004 & $10^{\circ} 2.156^{\prime}$ & $54^{\circ} 32.634^{\prime}$ & 8.0 \\
PF12-11 & 19.05 .2004 & $10^{\circ} 2.392^{\prime}$ & $54^{\circ} 32.452^{\prime}$ & 11.0 \\
PF12-13 & 19.05 .2004 & $10^{\circ} 2.651^{\prime}$ & $54^{\circ} 32.262^{\prime}$ & 13.0 \\
PF12-24 & 19.05 .2004 & $10^{\circ} 2.507^{\prime}$ & $54^{\circ} 32.019^{\prime}$ & 24.0 \\
PF12-27 & 19.05 .2004 & $10^{\circ} 2.624^{\prime}$ & $54^{\circ} 31.942^{\prime}$ & 27.0 \\
PO220-35-2 & 09.07 .1996 & $10^{\circ} 0.19^{\prime}$ & $54^{\circ} 47.04^{\prime}$ & 26.3 \\
PO220-37-2 & 10.07 .1996 & $10^{\circ} 15.98^{\prime}$ & $54^{\circ} 27.66^{\prime}$ & 18.6 \\
\hline
\end{tabular}

Table 1. Coordinates and water depths of surface sediment samples analysed in this study.

weighed. The $63-2000 \mu \mathrm{m}$ size fraction was considered in order to allow comparison with previous foraminiferal studies in this area (Lutze, 1965, 1974; Wefer, 1976). Aliquots were made with an Otto microsplitter, and living foraminifers were picked under a dissecting microscope. The specimens were transferred to Plummer cell slides, sorted at species level, fixed with glue and counted. They were compared with reference slides of Lutze (1965) curated at the Micropalaeontology Unit, Institute of Geosciences at Kiel University. The taxonomic concepts, especially the morphological variability of Elphidium excavatum subspecies, were calibrated with this reference material (Appendix A).

The phytoplankton concentrations in the water column were measured with hydrocasts using a Moldaenke bbe FluoroProbe fluorometer on each cruise at the $23.5 \mathrm{~m}$ monitoring site. The device was lowered with $0.2 \mathrm{~m} \mathrm{~s}^{-1}$ and the fluorescence of algal pigments induced by monochromatic light of 525, 570, 590 and $610 \mathrm{~nm}$ was recorded every second. The concentrations of different phytoplankton taxa are calculated from the backscatter. However, the concentrations of the two most abundant phytoplankton groups in the study area, i.e. Bacillariophyceans and Dinophyceans, were put together because of their similar fluorescence spectrum. Temperature and salinity measurements were also performed on every cruise at the monitoring site with a WTW Profiline 197 T-S probe in $1 \mathrm{~m}$ depth intervals.

The deposition of organic detritus was assessed with chlorine measurements. Subsamples of $3 \mathrm{~cm}^{3}$ were taken from the surface sediment samples with a syringe. The subsamples were transported under dark and cold conditions, and they were freezedried in opaque vessels immediately after the cruises. The samples were ground with an agate mortar and chlorophyll- $a$, phaeopigments and total chlorines were determined with a Turner TD700 Fluorometer using standard methods (Harris et al., 1996; Nürnberg et al., 2004).

\section{RESULTS}

\section{Hydrography}

The temperature and salinity measurements at the $23.5 \mathrm{~m}$ monitoring station depicted the successive formation of a boundary layer between Surface Water and Kattegat Water from deep winter mixing in January 2004 (Fig. 2). The gradients between the water masses steepened at 16-18 $\mathrm{m}$ water depth in February 2004. This was effected by a homogenization, i.e. turbulent mixing of the Surface Water and a slight freshening and warming of the Kattegat Water. The boundary layer suddenly deepened to below $20 \mathrm{~m}$ between 4 and 11 March 2004. The $23.5 \mathrm{~m}$ site was most likely intermittently bathed by Surface Water during these days. Summer stratification, with lowered Surface Water salinities and higher temperatures in the Surface Water, as compared to the Kattegat Water, was established between 5 April and 6 May. The salinity of the Kattegat Water increased thereafter from 17.5 to 21 units. The Kattegat Water temperature increased by $6^{\circ} \mathrm{C}$ in June to the same amount as in the Surface Water during April. The boundary layer of the summer stratification was again centred at 16-18 m water depth.

\section{Plankton dynamics}

The FluoroProbe measurements revealed that the majority of the phytoplankton lived in the Surface Water (Fig. 3). The concentrations decreased markedly in the boundary layer, but there was always a small maximum directly above the boundary layer. This maximum indicated the deceleration and concentration of sinking organic detritus at the boundary. High algal concentrations within two metres above the sea floor were observed only intermittently, at the monitoring site, stations PF1, PF6-PF8 and PF 10. Bacillariophyceans and Dinophycean levels showed a profound increase in the Surface Water between 13 and 17 February, which indicated the onset of the spring bloom. The decline of their concentrations between 4 and 11 March depicted the end of the spring bloom. The deepening of the hydrographical boundary layer during these days led to higher algal concentrations in near-bottom waters and thus most likely promoted the sedimentation of organic detritus (Fig. 2). This was displayed by high algal concentrations close to the sea bed three weeks later on the 5 April. The main spring bloom was followed by a series of summer blooms. They showed the highest high algal concentrations a few metres above the boundary layer and lower concentrations in upper waters. However, the monthly monitoring from May to July was too sparse to describe the summer blooms in detail.

\section{Phytodetritus deposition}

Chlorine concentrations in surface sediments varied between 27000 and $461000 \mathrm{ng} \mathrm{g}^{-1}$ dry sediment. Three distinct maxima were superimposed on a general trend of slightly increasing values with time. The maxima were recorded at stations PF2, PF7 to PF8 and at station PF11 (Fig. 4). The latter maximum was most prominent and showed three to four times higher chlorine concentrations than at the previous maxima. The 


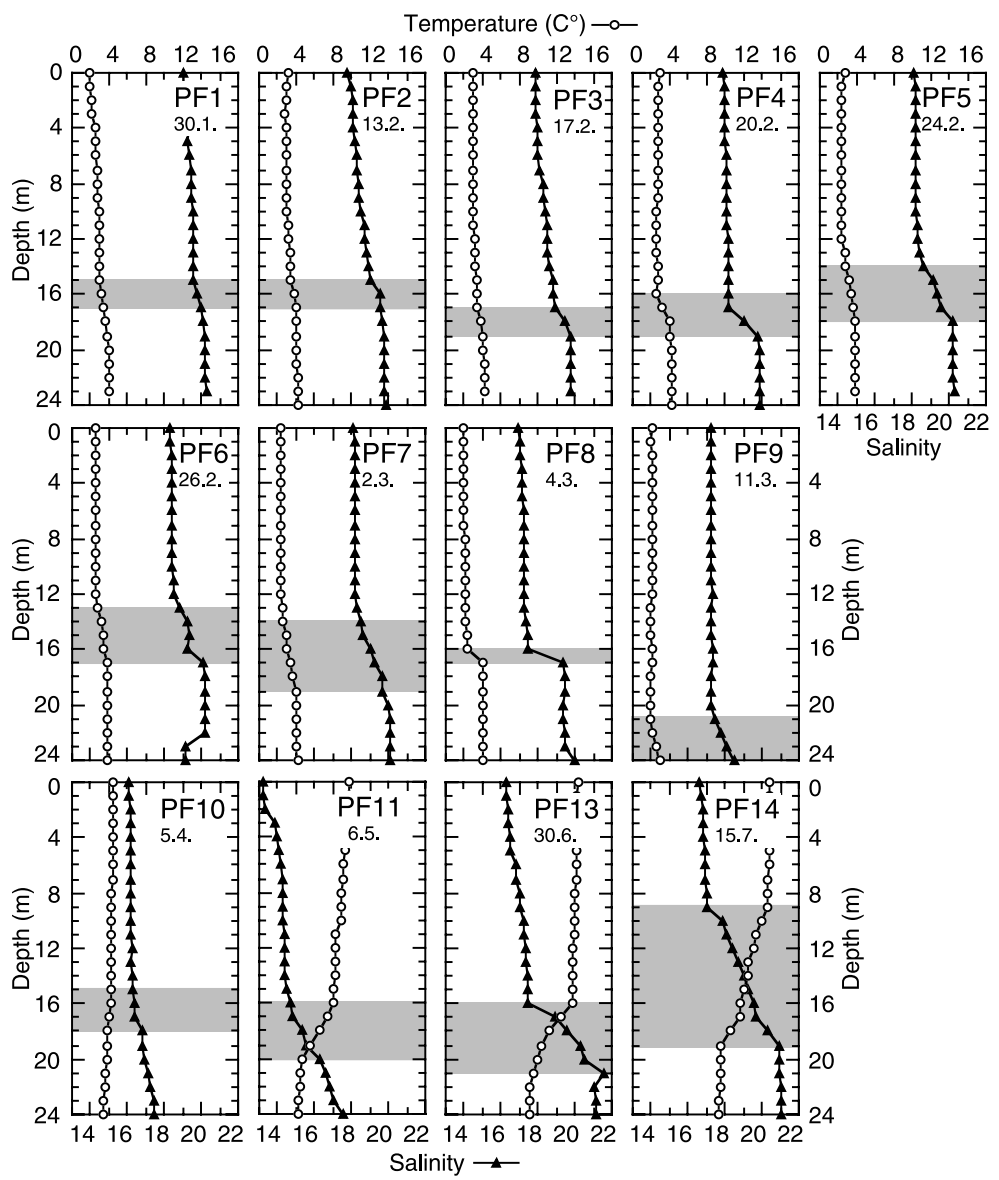

Fig. 2. Temperature- and salinity-depth sections at stations PF1 to PF14. The grey bar depicts the boundary layer between the Surface Water and the Kattegat Water below.

individual components of chlorines are phaeopigments depicting old, partly decomposed organic detritus and chlorophyll- $a$ representing fresh algal material. The ratio between phaeopigments and chlorophyll- $a$ was high at the first maximum in midFebruary, intermediate at the second maximum in early March and comparatively low at the third maximum at the beginning of May. The chlorine maxima were always preceded by high algal concentrations close to the sea floor as recorded by the FluoroProbe at stations PF1, PF6-PF8 and PF 10 (Fig. 3). The chlorine maxima are therefore considered to display pulses of phytodetritus deposition. The first pulse happened in the first two weeks of February, most likely promoted by the low density contrast between Surface and Kattegat Water. However, the high phaeopigment/chlorophyll- $a$ ratio indicates a considerable proportion of older, refractory organic material. The second pulse shortly preceded the end of the spring bloom. The successive lowering of the high algal concentrations close to the sea floor between 26 February and 4 March indicated that the main deposition happened between 2 and 4 March. The third pulse most likely happened in mid-April, shortly after the time when the spring bloom ceased. The hydrographical boundary layer was displaced to greater depth, and the lowermost Surface Water with high algal concentrations was in short contact with the sea floor (Fig. 2). This is in agreement with the low phaeopigment/chlorophyll- $a$ ratio at station PF11 indicating the fresh condition of organic detritus (Fig. 4).

\section{Response of foraminiferal assemblages}

The living foraminiferal assemblages at the $23.5 \mathrm{~m}$ monitoring site were dominated by Elphidium excavatum clavatum ranging from $66.1 \%$ to $99.5 \%$. It was followed by $E$. excavatum, E. incertum and Ammonia beccarii with $\leq 5.0 \%$ (Fig. 5, Appendix B, Plate 1). Ammotium cassis, Eggerelloides scaber and Reophax dentaliniformis regularis and other arenaceous species were rare, and they were missing at stations PF2 and PF8-PF11. Their proportion may have been surpressed by a successive increase of the proportion of E. excavatum clavatum from station PF7-PF11. The increasing dominance of E. excavatum clavatum and the temporary lack of arenaceous species coincided with organic detritus deposition during the second and third phytodetritus pulses (Fig. 4). Indicator species for either food deficit or phytodetritus deposition (e.g. Gooday, 1988; Gooday \& Turley, 1990) were not recognized. However, Elphidium albiumbilicatum was found only at station PF1 and, with significant proportions, also at station PF13, but the reason for these intermittent occurrences is unclear (Fig. 5). Miliammina fusca and Ammoscalaria runiana were also recorded sporadically. These species were reported to inhabit lag sediment at shallower-water depth (Lutze, 1965, 1974). Their occurrence at the $23.5 \mathrm{~m}$ monitoring site was, however, not related to periods with stronger winds and wave action (L. Numberger, pers. comm.). A displacement of living individuals of $M$. fusca and $A$. runiana by erosion and redeposition down slope is 

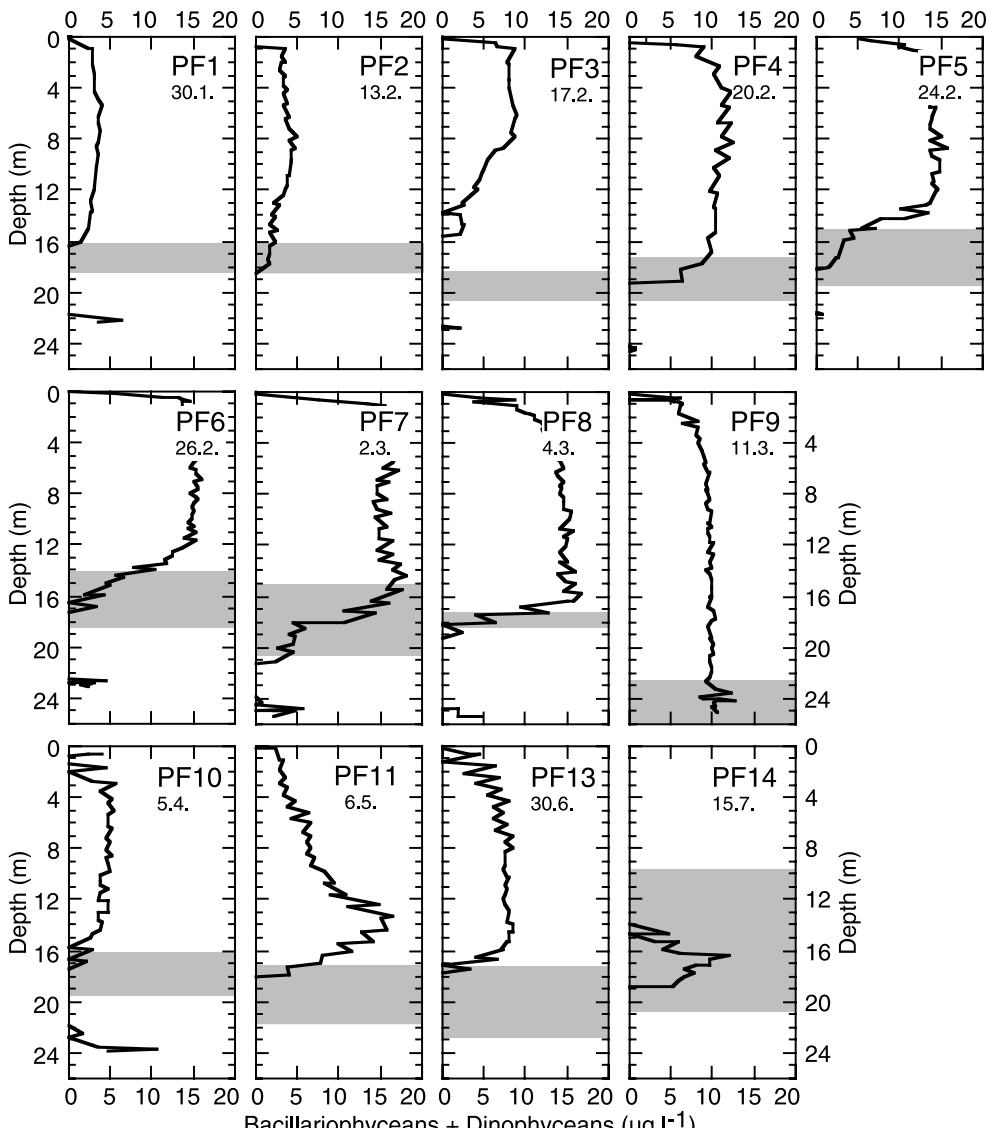

Fig. 3. Algal concentration-depth sections measured with the FluoroProbe at stations PF1 to PF14. The grey bar depicts the boundary layer between Surface Water and Kattegat Water. Note the successive sedimentation of organic detritus in the near-bottom water at stations PF6 to PF8.

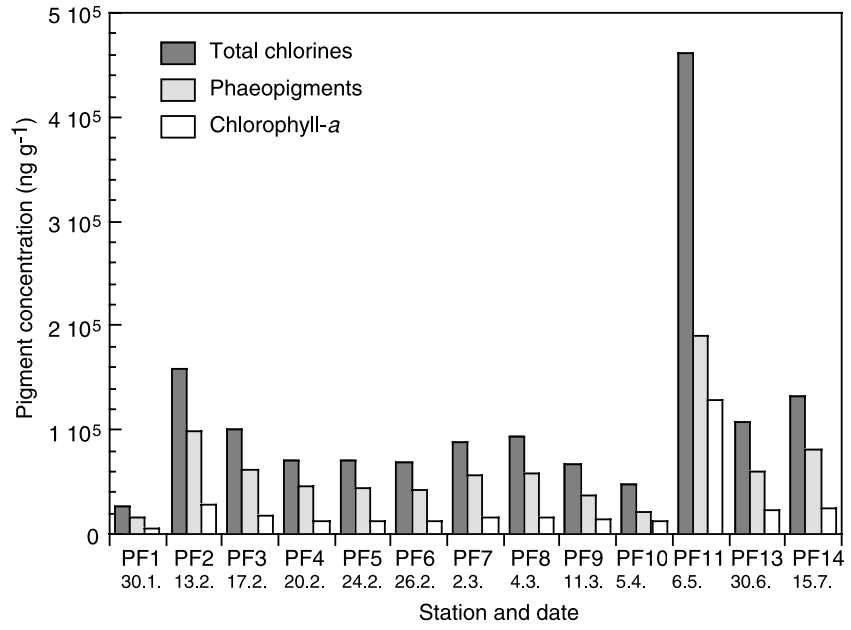

Fig. 4. Chlorine, phaeopigment and chlorophyll- $a$ concentrations in the surface sediment at the monitoring site (stations PF1 to PF14).

therefore less likely. The occurrence may have reflected, however, short-term lateral extensions of their distribution area to greater depths.

The standing stock also showed a strong dynamic, with three maxima at stations PF3, PF8 and PF11 (Fig. 6). The maxima at stations PF8 and PF11 followed the second and third depositional pulses of organic detritus (Fig. 4). However, the amplitude of standing stock maxima was different when compared to the fluctuations of chlorine concentrations. The highest standing stock at station PF3 followed the first organic detritus pulses with a time lag of five days, and it coincided with the beginning of the spring bloom. A small occurrence of algal remains in near-bottom waters at station PF3 may point to intermitted, short depositional pulses at the beginning of the spring bloom (Fig. 3), yet they were not mirrored by chlorine concentrations in the surface sediments. A six-fold increase in the standing stock in conjunction with onset of spring bloom, and a doubling together with the second and third phytodetritus pulses, indicated a short-term response of the benthic foraminiferal assemblages. The strong and immediate increases in foraminiferal population density that were almost entirely effected by $E$. excavatum clavatum suggested a fast reproduction, with high offspring numbers of this species in response to enhanced phytodetritus deposition.

\section{Comparison with the faunal dynamics in 1974 and 1975}

The dominant species at the $23.5 \mathrm{~m}$ monitoring site off Bokniseck was Elphidium incertum followed by Ammotium cassis, Hippocrepina flexilis and Reophax dentaliniformis regularis, with average proportions of $51.9 \%, 32.0 \%, 8.3 \%$ and 5.6\% in January to July 1974 and in spring 1975 (Appendix C) 


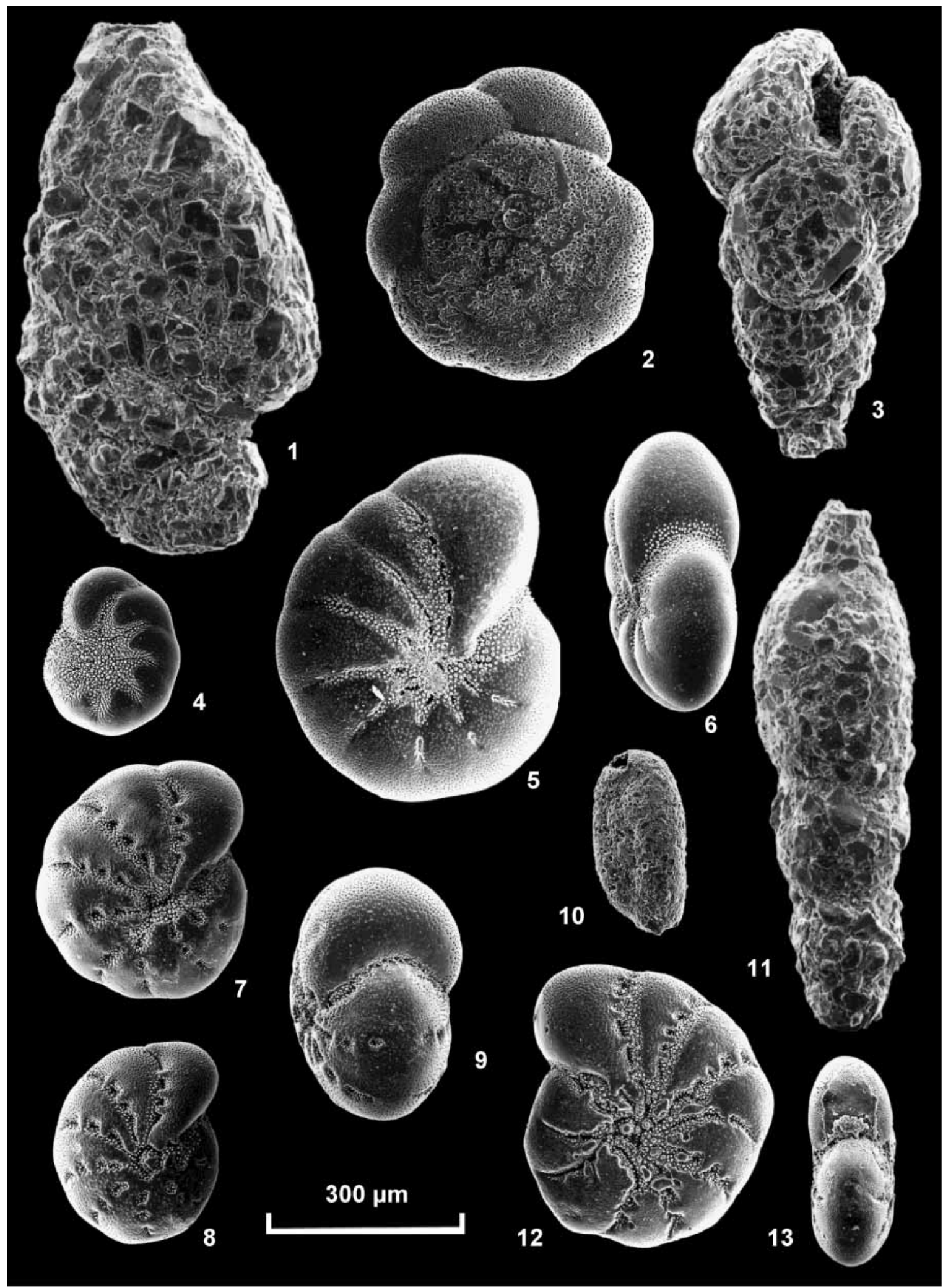

Explanation of Plate 1.

fig. 1. Ammotium cassis (Parker, 1870). fig. 2. Ammonia beccarii (Linné, 1758). fig. 3. Eggerelloides scaber (Williamson, 1858). fig. 4. Elphidium albiumbilicatum Weiss, 1954. figs 5-6. Elphidium incertum (Williamson, 1858). figs 7-9. Elphidium excavatum clavatum Cushman, 1930. fig. 10. Miliammina fusca (Brady, 1870). fig. 11. Reophax dentaliniformis regularis Höglund, 1947. figs 12-13. Elphidium excavatum excavatum (Terquem, 1875). The images were produced with a CAM-SCAN scanning electron microscope at the Institute for Geosciences, Kiel University. 


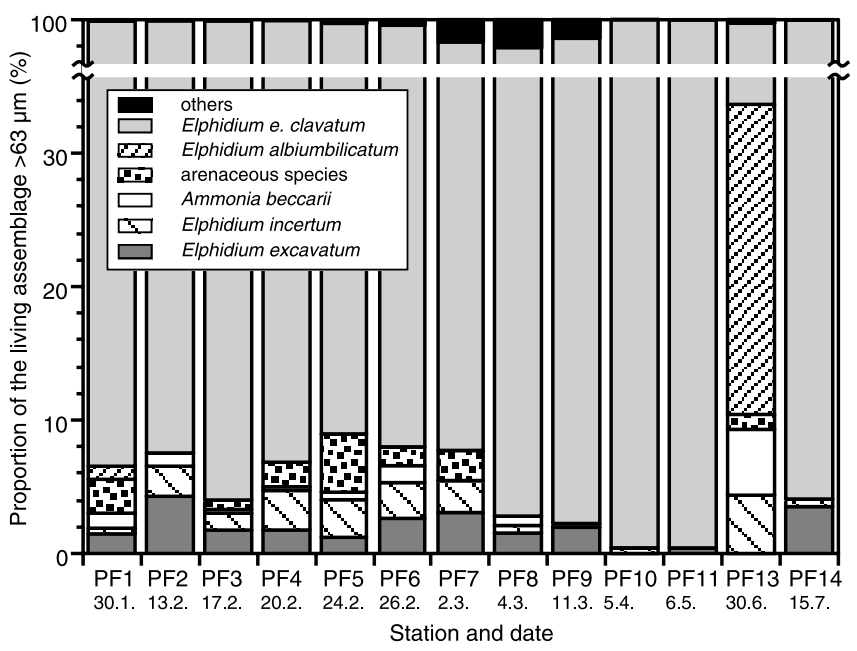

Fig. 5. Cumulative percentages of living benthic foraminifera at the monitoring site (stations PF1 to PF14). The most abundant species is Elphidium excavatum clavatum. Note the scale break between $36 \%$ and $97 \%$.

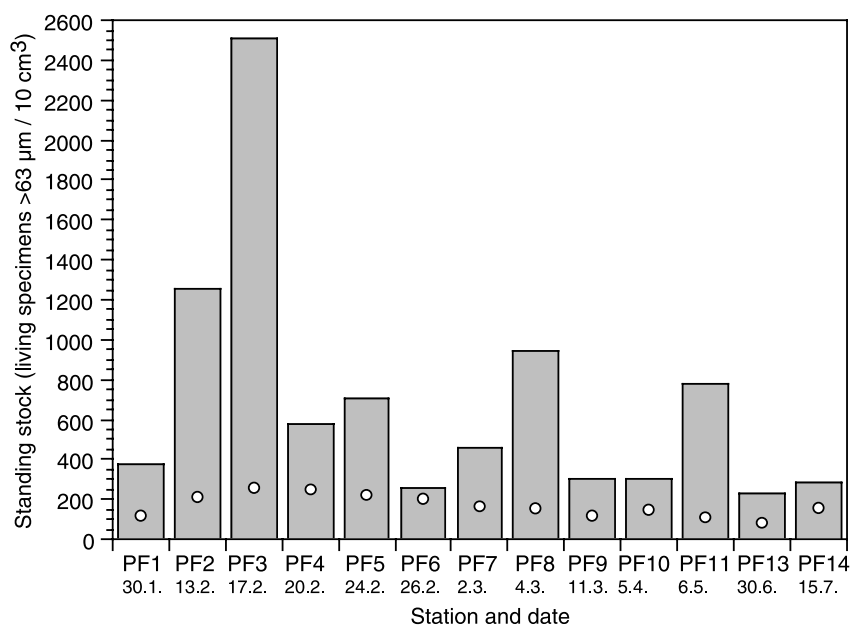

Fig. 6. Standing stock of benthic foraminifera at the monitoring site (stations PF1 to PF14). The circles depict the standing stock in 1974 which was interpolated to the respective sampling day in 2004 from the data of Wefer (1976) (Appendix C). Note the higher background level and much higher variability in foraminiferal population density in 2004 as compared to 1974.

(Wefer, 1976). E. excavatum clavatum was dominant in 2004, but it was only the fifth-ranked species in the mid-1970s. It fluctuated during spring and early summer from $0.6 \%$ to $29 \%$. Such a high dynamics is mirrored by a standard deviation of $\pm 7.47 \%$ which is not less than 1.6 times the mean value of $4.7 \%(n=16)$. As such, E. excavatum clavatum showed a much stronger seasonal variability than the four higher-ranked species, where the standard deviation ranged from 0.33 to 0.85 of their mean proportions.

The standing stock, with 47 to 267 living specimens per $10 \mathrm{~cm}^{3}$, also showed strong fluctuations during the first seven months of 1974 (Fig. 6) (Wefer, 1976). The maximum values were 5.7 times the minimum population densities in 1974 . The maximum standing stock was 2505 specimens in spring 2004, which is about 11 times as high as the minimum value of 227 specimens per $10 \mathrm{~cm}^{3}$ (Fig. 6). The variability of population densities in 2004 was therefore about twice as high as in 1974. The average population density in 2004, with 691 specimens per $10 \mathrm{~cm}^{3}$, was 5.6 times as high as in the first seven months of 1974 and 1975, where the average was 117 specimens (Appendices B, C). The faunal change from 1974 to 2004 is therefore not only apparent by a different species composition but also by elevated and more variable population densities in 2004. This is also depicted by the change in relative and absolute abundances of Elphidium species and subspecies, in particular E. excavatum clavatum (Figs 7, 8).

The dynamics of this subspecies can be described by a model calculation. The average examined sample volume from 1974 is left constant and the population density of the entire assemblage increased by a factor of 5.6, which is the difference of the average population densities at the $23.5 \mathrm{~m}$ monitoring site between the mid-1970s and 2004. If the density of the entire foraminiferal population is raised by increasing only the absolute abundance of E. excavatum clavatum, the proportion of this species would increase from $4.7 \%$ to $89.8 \%$ (Table 2 ). This projection is in good agreement with the situation in 2004 where E. excavatum clavatum on average comprised $92 \%$ of the living fauna. The average proportion of all arenaceous species would decrease from $50.7 \%$ to $5.0 \%$ by this projection. Their average proportion was in fact only $1.3 \%$ in 2004 . The raising of $E$. excavatum clavatum may therefore account well for the faunal change from 1974 to 2004 at the $23.5 \mathrm{~m}$ monitoring site. A strong increase in E. excavatum clavatum on decadal and shorter time-scales after a major ecological event has been described from the fossil record and recent environments in subarctic seas (Korsun \& Hald, 2000; Andrews et al., 2001; Principato et al., 2005). The results of the present study suggest the immediate response to elevated food supply as reason for the opportunistic behaviour of this Elphidium subspecies.

\section{Decadal changes in foraminiferal assemblages}

The composition of the living foraminiferal assemblages from $7 \mathrm{~m}$ to $27 \mathrm{~m}$ water depth in 2004 was compared to earlier studies in the 'Hausgarten' area (Lutze, 1965, 1974; Wefer, 1976). Elphidium excavatum, Ammotium cassis and E. incertum dominated the living assemblages in 1962 (Fig. 7), and Elphidium excavatum showed the highest absolute abundances (Fig. 8). Elphidium excavatum was suppressed by $A$. cassis and $E$. incertum at depths of and below the hydrographical boundary layer in 1971. A. cassis and E. incertum showed a deepening of their abundance maxima from $5 \mathrm{~m}$ to $16 \mathrm{~m}$ and $15 \mathrm{~m}$ to $23 \mathrm{~m}$, respectively. Furthermore, E. excavatum clavatum became established in the deep areas. The faunal change between 1962 and 1971 was therefore at least as great as that with 2004. E. excavatum clavatum successively protruded to shallower depths. The proportion of $A$. cassis decreased in the mid-1970s, the maximum deepened further. The absolute abundance of $A$. cassis was rather constant between 1962 and 1973 at depths of its maximum and decreased thereafter. The survey from 2004 revealed that $E$. excavatum dominated the living assemblage above the boundary layer and E. excavatum clavatum dominated the fauna below. Both subspecies comprised more than $90 \%$ of the living assemblage. The absolute abundance of E. excavatum clavatum at depth was more than twice as high as in 1975. 

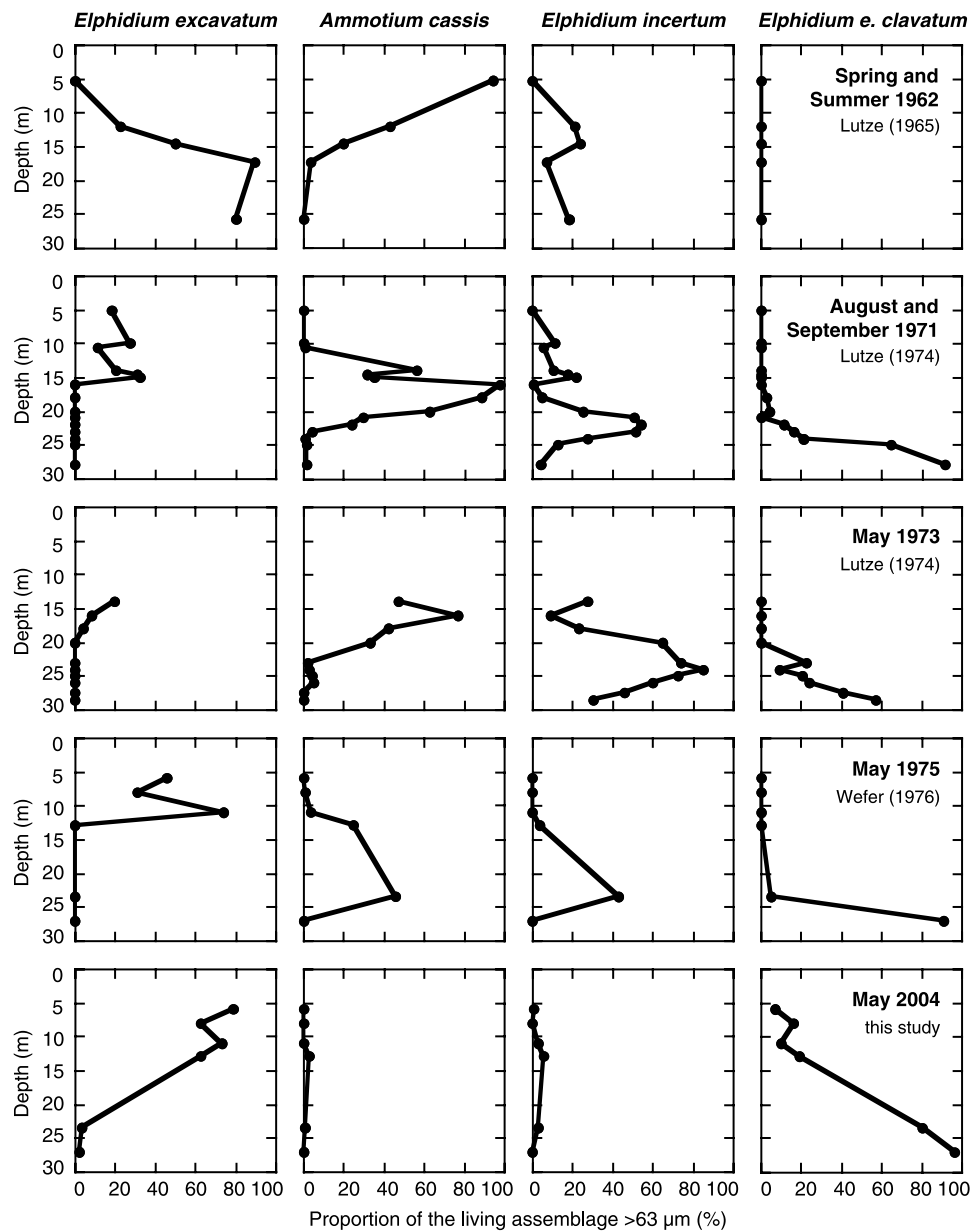

Fig. 7. Depth-distribution and abundance of the four-ranked species from 1962 to 2004 (data from Lutze, 1965, 1974; Wefer, 1976; this study). Note the successive displacement and decline of Elphidium incertum and Ammotium cassis.

Arenaceous species, in particular $A$. cassis, were very rare in 2004. Ammotium cassis was common (one of five living specimens) at $14 \mathrm{~m}$ and frequent (three out of five living specimens) at $18 \mathrm{~m}$ water depth in the 'Hausgarten' area in April 1985 as revealed by scuba-diving samples of P. Linke, Kiel. Two other samples from Kiel Bight taken in July 1996 showed a high proportion of $A$. cassis (nine out of ten living specimens) at $19 \mathrm{~m}$, and of $6 \%$ at $26 \mathrm{~m}$ water depth. The abundance and depth distribution in the mid-1980s and 1990s was therefore still in reasonable agreement with the situation in 1962 and in the early 1970s (Lutze, 1965, figs 13, 15; 1974, figs 9, 12). As such, the strong decline of $A$. cassis in the western Kiel Bight has most likely occurred during the last ten years.

\section{The decline of Ammotium cassis}

The recent diminution of $A$. cassis poses the question which kind of environmental variation controls the abundance of this species. In the fjords of western Sweden, this species shows distinct abundance peaks in hydrographic boundary layers where high concentrations of food particles prevail (Olsson, 1976). Ammotium cassis can withstand oxygen concentrations as low as $0.5 \mathrm{ml} \mathrm{l}^{-1}$, average salinities of at least 16 units and a wide temperature range of -0.5 to $19^{\circ} \mathrm{C}$. The regional distribution suggests a relationship with salinity rather than with temperature (Lutze, 1965; Olsson, 1976). Other studies conclude, however, that the temperature is limiting, as this species reproduces only at temperatures of less than $8^{\circ} \mathrm{C}$ (Wefer, 1976). Ammotium cassis is assigned a Northern Hemisphere cold-water species (Murray, 1973). It apparently colonized the Kattegat and Baltic Sea between 1932 and 1949 (Lutze, 1965; Olsson, 1976; Christiansen et al., 1996). The few historical environmental data suggest a slight rise in average summer temperatures at depths from $7.5^{\circ} \mathrm{C}$ in 1954 to $9.6^{\circ} \mathrm{C}$ in 2004 , and a reduction of average summer salinities from 25.9 to 20.9 units from 1966 to 2004 in the Kiel Bight (Wüst \& Brockmus, 1955; Magaard \& Rheinheimer, 1974; this study). These values are still in the range of environmental tolerances of $A$. cassis and they do not explain their recent diminution. Continuous records of temperature and salinity are available for the Gotland Basin at $200 \mathrm{~m}$ water depth (Fonselius, 1962; Matthäus, 1990; Nausch et al., 2003; Nausch et al., 2005) and for the Kattegat Water at Koljö Fjord, western Sweden, at 35-43 $\mathrm{m}$ depth (Fig. 9) (Filipsson \& Nordberg, 2004a). Both datasets display the water mass end-members of the Baltic Sea at depth, and they are considered to be significant for the Kiel Bight too. The temperature records of Gotland Basin and Koljö Fjord fluctuate around a constant level, whereas the Koljö Fjord data show a higher inter-annual variability linked to positive and negative NAO periods (Chen \& 

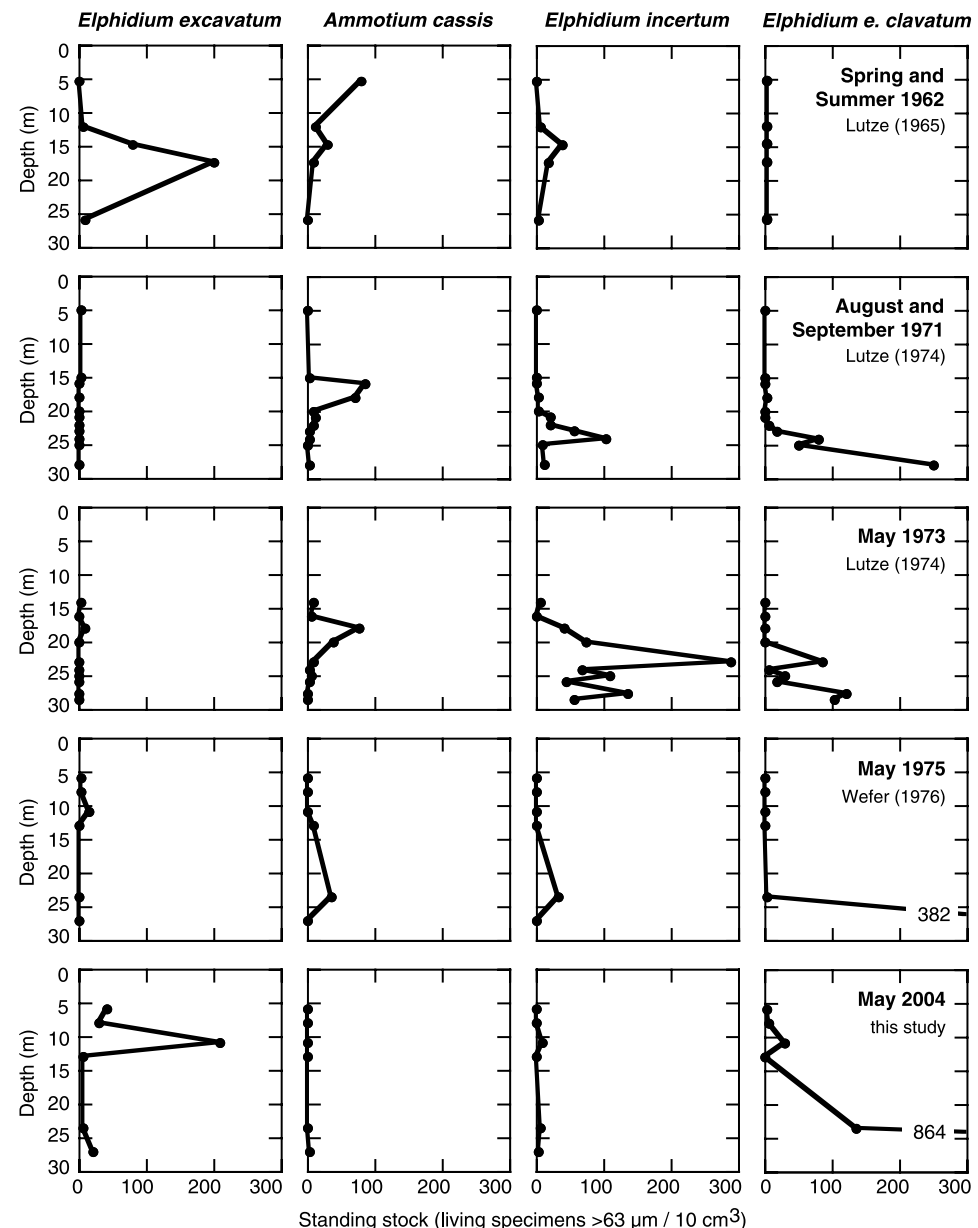

Fig. 8. Depth-distribution and standing stock of the four-ranked species from 1962 to 2004 (data from Lutze, 1965, 1974; Wefer, 1976; this study). Note the high variability of Elphidium species and the rather constant population density of Ammotium cassis where it occurs.

\begin{tabular}{|c|c|c|c|c|c|c|c|}
\hline & $\begin{array}{c}\text { Time } \\
\text { interval } \\
\text { studied }\end{array}$ & $\begin{array}{l}\text { Elphidium } \\
\text { excavatum } \\
\text { clavatum }\end{array}$ & $\begin{array}{c}\text { Other } \\
\text { calcareous } \\
\text { species }\end{array}$ & $\begin{array}{l}\text { Arenaceous } \\
\text { species }\end{array}$ & $\begin{array}{l}\text { Counted } \\
\text { specimens }\end{array}$ & $\begin{array}{l}\text { Standing stock } \\
\text { (Ind. } 10 \mathrm{~cm}^{-3} \text { ) }\end{array}$ & $\begin{array}{c}\text { Examined } \\
\text { sample } \\
\text { volume }\left(\mathrm{cm}^{3}\right)\end{array}$ \\
\hline Wefer (1976) (mean values) & $\begin{array}{c}5.1-16.7 .197 \\
9.1-14.05 .1975\end{array}$ & 4.7 & 44.6 & 50.7 & 180 & 116.8 & 15.41 \\
\hline \multicolumn{2}{|c|}{$\begin{array}{r}\text { Projection of } 1974 \text { and } 1975 \text { data to } 2004(n) \\
(\%)\end{array}$} & $\begin{array}{l}904 \\
89.8\end{array}$ & $\begin{array}{l}48 \\
4.7\end{array}$ & $\begin{array}{l}50 \\
5.0\end{array}$ & $\begin{array}{r}1002 \\
100\end{array}$ & 650.1 & 15.41 \\
\hline
\end{tabular}

Table 2. Projection of the foraminiferal assemblage composition from spring and early summer 1974 to population densities of 2004 by increasing the number of Elphidium excavatum clavatum.

Hellström, 1999; Filipsson \& Nordberg, 2004a). The salinity trends of Gotland Basin and Koljö Fjord show a multi-decadal sawtooth pattern of successively decreasing salinities and sudden rises due to massive saltwater inbursts in certain years, e.g. in the late 1930s (Fonselius, 1962) and in 1993/1994 (Nausch et al., 2003). Major, submillennial salinity variations in the Baltic Sea reflect fluctuations of reconstructed summer warmth and winter precipitation in southern Scandinavia rather than NAO variability (Emeis et al., 2003). The low-salinity events in the late 1930s and early 1990s seemingly confine the period when Ammotium cassis was abundant in the Kiel Bight (Fig. 9).

\section{CONCLUSIONS}

The results of the present study indicated that pigments and thus the fresh, labile organic matter was decomposed quickly after deposition. The benthic foraminiferal fauna responded rapidly to depositional pulses of organic matter with only a few days delay. Such immediate response is on the same time-scale as in the deep sea (Gooday, 1988; Gooday \& Turley, 1990; Lambshead \& Gooday, 1990; Altenbach, 1992). However, the reaction of the foraminiferal assemblages was not characterized by specialized phytodetritus feeders, but by $E$. excavatum clavatum as a regular faunal element. This species apparently has 


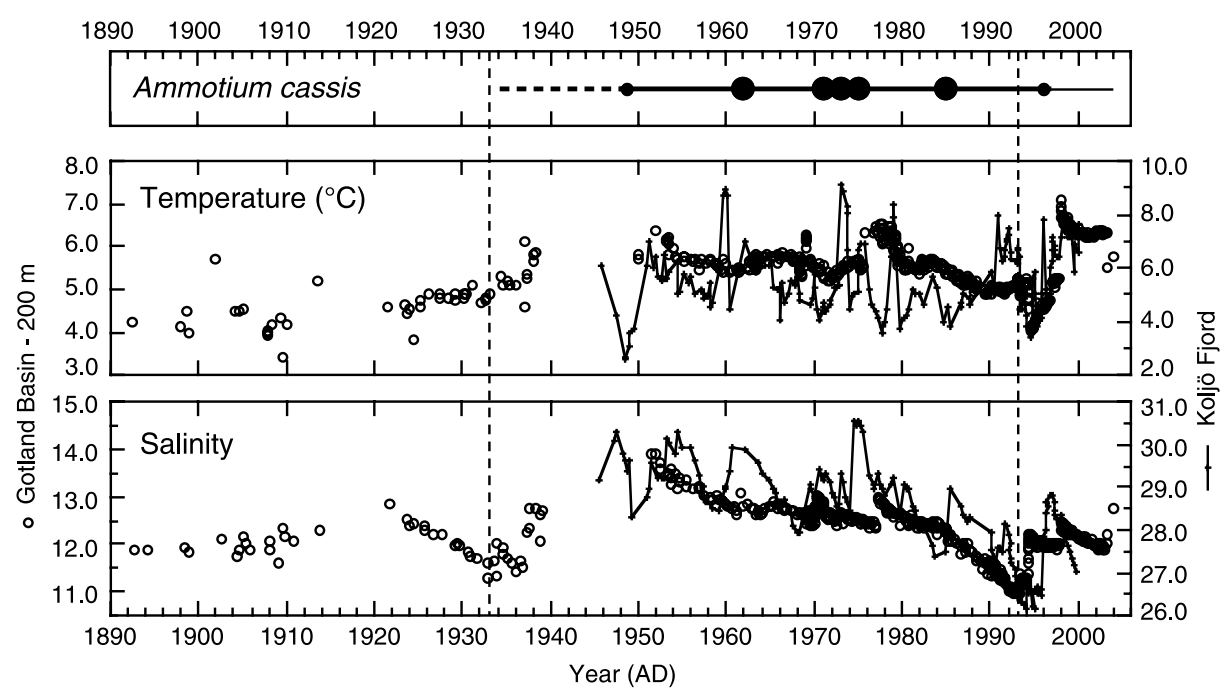

Fig. 9. The occurrence of Ammotium cassis in the Kiel Bight and multi-decadal variations of temperature and salinity of Baltic Sea waters at depth as depicted by end-member records of inflowing Kattegat Water from the Koljö Fjord (Filipsson \& Nordberg, 2004a) and remaining Deep Water from the Gotland Basin (Matthäus, 1990; Nausch et al., 2003, 2005). The abundance of Ammotium cassis is indicated semi-quantitatively (see text for data sources). Dashed line: uncertain occurrence; thin line: very rare; small dots: few; large dots: frequent. The dashed vertical lines mark the salinity minima of 1933 and 1993

a competition advantage in that it can quickly produce high offspring numbers within a few days only after increased food supply. The timespan of the life cycle of E. excavatum clavatum has been estimated to be 20 days (Haake, 1967). This short timespan, together with limited resources and space, could be a reason why the next generation has difficulties increasing to the same level as the parent generation (Altenbach, 1985; Murray, 2001). Thus, the population density of E. excavatum clavatum decreased again shortly after the depositional pulses but remained at high levels compared to the 1970s (Fig. 6). The reasons for the extraordinarily high population densities and the perennial predominance of E. excavatum clavatum in 2004 remain unclear. It appears to be rather unlikely that an increase in primary production by approximately $40 \%$ during the past 30 years has effected an increase in average population densities of $500 \%$. It could well be that better ventilation of the deep basins in the Baltic Sea and deep winter mixing since the mid-1990s has facilitated a more efficient nitrate recycling and thus much stronger spring blooms and enhanced phytodetritus deposition (Matthäus, 2001). Then both anthropogenic and natural influences would have facilitated the present high population densities of E. excavatum clavatum in the 'Hausgarten' area.

The coincidence of the immigration and diminution of $A$. cassis with periods of low deep-water salinity in the Baltic Sea suggests that such years were endangering this species. The low salinity and thus density difference between Surface and Kattegat Water during the respective periods probably inhibited the development of a robust hydrographic boundary layer at depth in late spring when A. cassis reproduces (Wefer, 1976). Food concentrations were then insufficient for successful reproduction and this would either obstruct an immigration of $A$. cassis to this area, or it would lead to a strong decline in the case of an existing A. cassis population during the following years. This faunal response to environmental change resembles the response to cyclical changes in periodically flushed basins driven by natural climate variability (Alve, 1991, 1995; Bernhard \&
Reimers, 1991; Murray, 2000; Filipsson \& Nordberg, 2004b). These studies suggest that faunal recovery after re-establishing of favourable conditions may take more than one year, and that highly opportunistic species are the first colonizers. The dense populations of Elphidium excavatum clavatum have occupied the former habitats of A. cassis in the 'Hausgarten' area, however. Together with a substantial warming of Baltic Sea deep waters since 1996, these opportunists may well have impeded the re-establishment of $A$. cassis populations at Kiel Bight in the early 2000 s.

\section{ACKNOWLEDGEMENTS}

Michael Spindler and Klaus von Bröckel (Kiel) gave advice, provided equipment and ship time. Wolfgang Kuhnt provided samples from $R / V$ Poseidon cruise 220 and gave access to the reference slides of G.-F. Lutze at the Micropalaeontology Unit, Institute of Geosciences, Kiel University. Peter Linke (Kiel) provided information on samples and unpublished material from the 'Hausgarten' area. Jutta Heinze and Beate Bader (Kiel) provided laboratory facilities, Thorsten Meyer and Helmut Schramm helped LN with the sampling on board $R / V$ Polarfuchs. Their encouragement, effort and support are gratefully acknowledged. The authors thank John Murray and Karen Luise Knudsen for their constructive comments and suggestions on an earlier version of this paper.

\section{Benthic foraminiferal species considered in this paper}

Taxonomic references are given by Lutze (1965) and Haynes (1973); they are not included in the reference list.

Ammonia beccarii $($ Linné) $=$ Nautilus beccarii Linné, 1758

Ammoscalaria runiana (Heron-Allen \& Earland)= Haplophragmium runianum Heron-Allen \& Earland, 1916 Ammotium cassis $($ Parker $)=$ Lituola cassis Parker, 1870 Eggerelloides scaber $($ Williamson $)=$ Bulimina scabra Williamson, 1858 (Note: Eggerelloides scabrus or Eggerella scabra of authors). 
Seasonal changes, Foraminifera, Baltic Sea

Elphidium albiumbilicatum (Weiss)=Nonion pauciloculum Cushman subsp. albiumbilicatum Weiss, 1954 (Note: Elphidium asklundi Brotzen, 1943 of Lutze (1965)).

Elphidium excavatum excavatum (Terquem)=Polystomella excavata Terquem, 1875 (Note: Elphidium excavatum forma selseyensis of authors).

Elphidium excavatum clavatum Cushman, 1930

Elphidium gerthi van Voorthuysen, 1957
Elphidium incertum (Williamson)=Polystomella umbilicatula (Walker) var. incerta Williamson, 1858

Eoponidella pulchella (Parker)=Pninaella? pulchella Parker, 1952 Hippocrepina flexilis (Wiesner)=Technitella flexilis Wiesner, 1931

Laryngosigma hyalascidae Loeblich \& Tappan, 1953

Miliammina fusca (Brady)=Quinqueloculina fusca Brady, 1870

Reophax dentaliniformis regularis Höglund, 1947

Census data of the living assemblage 63-2000 $\mu \mathrm{m}$

\begin{tabular}{|c|c|c|c|c|c|c|c|c|c|c|c|c|c|}
\hline Station & 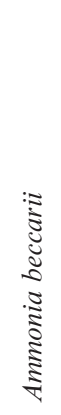 & 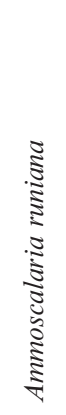 & 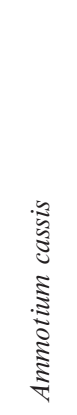 & 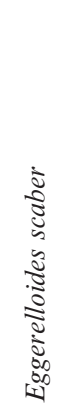 & 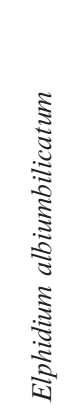 & 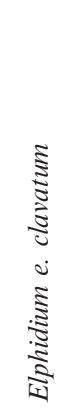 & 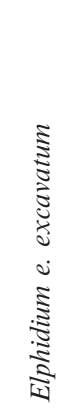 & 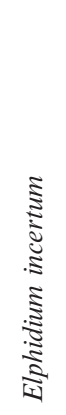 & 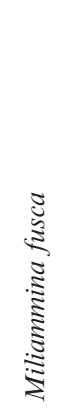 & 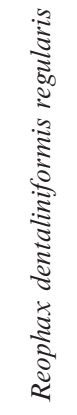 & $\frac{\tilde{\omega}}{\stackrel{5}{0}}$ & 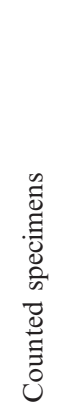 & 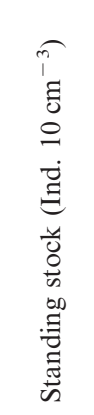 \\
\hline PF1 & 1.0 & & 1.0 & 0.5 & 1.0 & 93.4 & 1.5 & 0.5 & & 1.0 & & 196 & 377 \\
\hline PF2 & 1.0 & & & & & 92.4 & 4.3 & 2.3 & & & & 301 & 1252 \\
\hline PF3 & 0.3 & & & 0.3 & & 96.0 & 1.9 & 1.2 & & 0.3 & & 321 & 2505 \\
\hline PF9 & & 0.3 & & & & 96.3 & 2.0 & 0.3 & & & 1.1 & 349 & 302 \\
\hline PF10 & & & & & & 99.5 & & 0.5 & & & & 206 & 306 \\
\hline PF11 & & & & & & 99.5 & 0.5 & & & & & 425 & 778 \\
\hline PF13 & 5.0 & 0.3 & 0.3 & & 23.1 & 66.1 & & 4.4 & & 0.8 & & 363 & 227 \\
\hline PF14 & & & & & & 95.9 & 3.6 & 0.5 & & & & 197 & 287 \\
\hline Mean & 1.3 & 0.6 & 0.7 & 0.8 & 12.1 & 92.3 & 2.2 & 1.8 & 0.2 & 0.8 & 1.7 & 308 & 690.5 \\
\hline Std dev. & 1.6 & 0.5 & 0.4 & 0.7 & 15.6 & 8.4 & 1.1 & 1.3 & & 0.3 & 0.8 & & \\
\hline PF12-6 & 2.5 & & & & 10.7 & 7.4 & 78.7 & 0.8 & & & & 122 & 53 \\
\hline PF12-8 & 1.3 & & & & 18.7 & 16.0 & 62.7 & & 1.3 & & & 150 & 45 \\
\hline PF12-11 & 9.0 & & & & & 10.0 & 73.0 & 3.0 & & 2.0 & 3.0 & 93 & 286 \\
\hline PF12-13 & & & 3.0 & & & 19.0 & 63.0 & 6.0 & & & 9.0 & 32 & 8 \\
\hline PF12-24 & 3.7 & & 0.7 & & 7.4 & 80.1 & 3.7 & 2.9 & & 0.7 & 0.7 & 136 & 170 \\
\hline
\end{tabular}

Numbers in brackets are counted specimens.

Table 3. Foraminiferal census data (percentages) of the living assemblage 63-2000 $\mu \mathrm{m}$. 


\begin{tabular}{|c|c|c|c|c|c|c|c|c|c|c|c|c|c|c|}
\hline Station & Date & 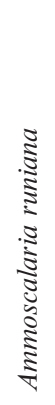 & 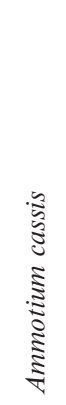 & 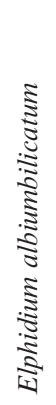 & 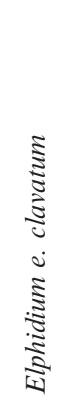 & 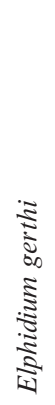 & 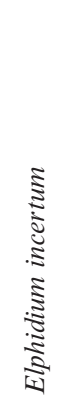 & 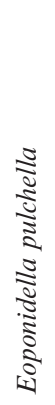 & 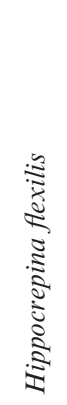 & 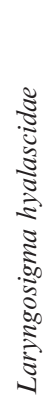 & 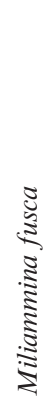 & 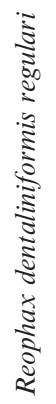 & 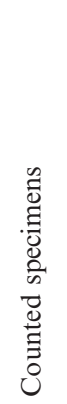 & 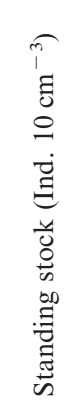 \\
\hline 12745 & 04.01 .1974 & & 5.1 & 1.9 & 1.3 & & 89.1 & & 2.0 & & & 0.6 & 156 & 194 \\
\hline 12754 & 15.01 .1974 & & 40.3 & & 1.3 & & 45.5 & & 3.0 & & 0.4 & 9.5 & 233 & 144 \\
\hline 12762 & 04.02 .1974 & & 14.9 & & 4.3 & & 70.2 & & 8.0 & & 0.5 & 2.1 & 188 & 114 \\
\hline 12765 & 18.02 .1974 & & 20.1 & 0.4 & & & 65.4 & & 12.2 & & 0.5 & 1.4 & 205 & 267 \\
\hline 12902 & 10.05 .1974 & 0.3 & 56.4 & & 0.6 & 0.4 & 20.0 & 0.3 & 14.1 & & 0.9 & 7.0 & 300 & 127 \\
\hline 12908 & 21.05 .1974 & & 52.4 & & 2.3 & & 38.8 & & & & & 6.5 & 260 & 151 \\
\hline 12914 & 30.05 .1974 & & 53.7 & & 2.1 & & 40.5 & 0.4 & 2.9 & 0.4 & & & 244 & 182 \\
\hline 12920 & 25.06 .1974 & & 43.2 & & 3.7 & & 50.8 & & & & 0.4 & 1.9 & 266 & 95 \\
\hline 12930 & 05.07.1974 & & 50.9 & 1.2 & 1.7 & & 45.0 & & & & 1.2 & & 169 & 59 \\
\hline 12991 & 09.01 .1975 & & 18.6 & 2.3 & 16.3 & & 41.9 & & & & & 20.1 & 43 & 29 \\
\hline 12997 & 06.02 .1975 & & 49.5 & & 1.9 & & 39.6 & & & & 1.0 & 7.8 & 103 & 36 \\
\hline 13003 & 17.03 .1975 & & 24.8 & 1.0 & 2.9 & & 67.6 & & & & & 3.8 & 105 & 58 \\
\hline 13010 & 10.04 .1975 & & 10.1 & & 29.0 & & 53.6 & & & & & 7.2 & 69 & 121 \\
\hline 13017 & 14.05 .1975 & & 45.6 & & 5.2 & & 42.8 & & 5.2 & & & 1.3 & 77 & 77 \\
\hline Mean & & 3.2 & 32 & 1.3 & 4.7 & 0.4 & 51.9 & 0.5 & 8.3 & 0.6 & 1.6 & 5.6 & 180 & 116.8 \\
\hline \multirow{2}{*}{\multicolumn{2}{|c|}{ Proportion of mean }} & 4.1 & 16.9 & 0.7 & 7.5 & & 16.9 & 0.2 & 5.5 & 0.3 & 2.7 & 4.7 & & \\
\hline & & 1.3 & 0.5 & 0.6 & 1.6 & & 0.3 & 0.4 & 0.7 & 0.5 & 1.7 & 0.9 & & \\
\hline
\end{tabular}

After Wefer (1976, table 23).

Table 4. Foraminiferal census data (percentages) of the living assemblage $>63 \mu \mathrm{m}$ at the $23.5 \mathrm{~m}$ monitoring site off Bokniseck during the first seven months of 1974 and 1975.

\section{Manuscript received 3 January 2006 Manuscript accepted 8 November 2006}

\section{REFERENCES}

Altenbach, A.V. 1985. Die Biomasse der benthischen Foraminiferen. Auswertungen von 'Meteor' - Expeditionen im östlichen Nordatlantik. Dissertation an der Christian-Albrechts-Universität zu Kiel: 133pp.

Altenbach, A.V. 1992. Short term processes and patterns in the foraminiferal response to organic flux rates. Marine Micropaleontology, 19: $119-129$.

Alve, E. 1991. Foraminifera, climatic change, and pollution: a study of late Holocene sediments in Drammensfjord, southeast Norway. The Holocene, 1: 243-261.

Alve, E. 1995. Benthic foraminiferal distribution and recolonization of formerly anoxic environments in Drammensfjord, southern Norway. Marine Micropaleontology, 25: 169-186.

Alve, E. 1996. Benthic foraminiferal evidence of environmental change in the Skagerrak over the past six decades. Bulletin Norges Geologiske Undersökelse, 430: 85-93.

Alve, E. \& Murray, J.W. 1995. Benthic foraminiferal distribution and abundance changes in Skagerrak surface sediments: 1937 (Höglund) and 1992/1993 data compared. Marine Micropaleontology, 25 269-288.
Andrews, J.T., Caseldine, C., Weiner, N.J. \& Hatton, J. 2001. Late Holocene (ca. $4 \mathrm{ka}$ ) marine and terrestrial environmental change in Reykjarfjordur, north Iceland: climate and/or settlement? Journal of Quaternary Science, 16: 133-143

Bernhard, J.M. \& Reimers, C.E. 1991. Benthic foraminiferal population fluctuations related to anoxia: Santa Barbara Basin. Biogeochemistry, 15: 127-149.

Bodungen, B. von 1975. Der Jahresgang der Nährsalze und der Primärproduktion des Planktons in der Kieler Bucht unter Berücksichtigung der Hydrographie. Dissertation an der Christian-AlbrechtsUniversität zu Kiel: 115pp.

Brodniewicz, I. 1965. Recent and some Holocene Foraminifera of the southern Baltic Sea. Acta Palaeontologica Polonica, 10: $131-248$.

Bröckel, K. von 1975. Der Energieflu $\beta$ im pelagischen Ökosystem vor Boknis Eck (westl. Ostsee). Reports Sonderforschungsbereich 95 Wechselwirkung Meer - Meeresboden, 10: 1-96.

Chen, D.L. \& Hellström, C. 1999. The influence of the North Atlantic Oscillation on the regional temperature variability in Sweden: Spatial and temporal variations. Tellus, 51A: 505-516.

Christiansen, C., Kunzendorf, H., Laima, M.J.C., Lund-Hansen, L.C. \& Pedersem, A.M. 1996. Recent changes in environmental conditions in the southwestern Kattegat, Scandinavia. Bulletin Norges Geologiske Undersökelse, 430: 137-144. 
Emeis, K.C., Struck, U., Blanz, T., Kohly, A. \& Voß, M. 2003. Salinity changes in the central Baltic Sea (NW Europe) over the last 10000 years. The Holocene, 13: 411-421.

Feistel, R., Nausch, G., Matthäus, W. \& Hagen, E. 2003. Temporal and spatial evolution of the Baltic deep water renewal in spring 2003. Oceanologia, 45: 623-642.

Filipsson, H.L. \& Nordberg, K. 2004a. A 200-year environmental record of a low oxygen fjord, Sweden, elucidated by benthic foraminifera, sediment characteristics and hydrographic data. Journal of Foraminiferal Research, 34: 277-293.

Filipsson, H.L. \& Nordberg, K. 2004b. Climate variations, an overlooked factor influencing the recent marine environment. An example from Gullmar Fjord, Sweden, illustrated by benthic foraminifera and hydrographic data. Estuaries, 27: 867-881.

Flemming, B.W. \& Wefer, G. 1973. Tauchbeobachtungen an Wellenrippeln und Abrasionserscheinungen in der westlichen Ostsee südöstlich Bokniseck. Meyniana, 23: 9-18.

Fonselius, S.H. 1962. Hydrography of the Baltic Deep Basins. Fischery Board Sweden. Series Hydrography, 13: 1-41.

Frenzel, P. 1996. Rezente Faunenverteilung in den Oberflächensedimenten des Greifswalder Boddens (südliche Ostsee) unter besonderer Berücksichtigung der Ostrakoden. Senckenbergiana maritima, 27: $11-31$.

Frenzel, P. \& Oertl, P. 2002. Die renzenten Ostrakoden und Foraminiferen des Strelasundes. Rostocker Meeresbiologische Beiträge, 11: $23-37$.

Gooday, A.J. 1988. A response by benthic Foraminifera to the deposition of phytodetritus in the deep sea. Nature, 332: 70-73.

Gooday, A.J. \& Turley, C.M. 1990. Responses by benthic organisms to inputs of organic material to the ocean floor: a review. Philosophical Transactions of the Royal Society London, Series A, 331: 119-138.

Gustafsson, M. \& Nordberg, K. 2001. Living (stained) benthic foraminiferal response to primary production and hydrography in the deepest part of the Gullmar Fjord, Swedish west coast, with comparisons to Höglund's 1927 material. Journal of Foraminiferal Research, 31 $2-11$.

Haake, F.-W. 1967. Untersuchungen an der Foraminiferen-Fauna im Wattgebiet zwischen Langeoog und dem Festland. Meyniana, 12 25-64.

Harris, P.G., Zhao, M., Rosell-Melé, A., Tiedemann, R., Sarnthein, M. \& Maxwell, J.R. 1996. Chlorin accumulation rate as a proxy for Quaternary marine primary productivity. Nature, 383: 63-65.

Haynes, J.R. 1973. Cardigan Bay Recent Foraminifera (Cruises of the R. V. Antur, 1962-1964. Bulletin of the British Museum (Natural History), Zoology Supplement, 4: 1-244.

Hermelin, J.O. 1987. Distribution of Holocene benthic foraminifera in the Baltic Sea. Journal of Foraminiferal Research, 17: 62-73.

Hurrell, J.W. 1995. Decadal trends in the North Atlantic oscillation and regional temperature and precipitation. Science, 269: 676-679.

Hällfors, G. \& Niemi, Å. 1986. Views of the use of phytoplankton as a parameter in monitoring the state of the Baltic sea. Baltic Sea Environment Proceedings, 19: 367-381.

Kaczmarek, S., Koblentz-Mishke, O.J., Ochocki, S., Nakonieczny, J. \& Renk, H. 1997. Primary production in the eastern and southern Baltic Sea. Oceanologia, 39: 117-135.

Korsun, S. \& Hald, M. 2000. Seasonal dynamics of benthic foraminifera in a glacially fed fjord of Svalbard, European Arctic. Journal of Foraminiferal Research, 30: 251-271.

Kreisel, K. \& Leipe, T. 1989. Zum Vorkommen rezenter benthischer Foraminiferen im Greifwalder Bodden. Wissenschaftliche Zeitschrift der Ernst-Moritz-Arndt-Universität Greifswald, 38: 98-104.

Lambshead, P.J.D. \& Gooday, A.J. 1990. The impact of seasonally deposited phytodetritus on epifaunal and shallow infaunal benthic foraminiferal populations in the bathyal northeast Atlantic: the assemblage response. Deep-Sea Research, 37: 1263-1283.

Lenz, H. 1974. Untersuchung zum Nahrungsgefüge im Pelagial der Kieler Bucht. Habilitationsschrift an der Christian-Albrechts-Universität zu Kiel: 144pp.

Lutze, G.-F. 1965. Zur Foraminiferen-Fauna der Ostsee. Meyniana, 15 $75-142$.

Lutze, G.-F. 1968a. Jahresgang der Foraminiferen-Fauna in der Bottsand-Lagune (westliche Ostsee). Meyniana, 18: 13-30.
Lutze, G.-F. 1968b. Siedlungs-Strukturen rezenter Foraminiferen. Meyniana, 18: 31-34.

Lutze, G.-F. 1974. Foraminiferen der Kieler Bucht (westliche Ostsee): 1. 'Hausgartengebiet' des Sonderforschungsbereiches 95 der Universität Kiel. Meyniana, 26: 9-22.

Lutze, G.-F. \& Altenbach, A.V. 1991. Technik und Significanz der Lebendfärbung benthischer Foraminiferen mit Bengalrot. Geologisches Jahrbuch, 128: 251-265.

Lutze, G.-F., Mackensen, A. \& Wefer, G. 1983. Foraminiferen der Kieler Bucht: 2. Salinitätsansprüche von Eggerella scabra (Williamson). Meyniana, 35: 55-65.

Magaard, L. \& Rheinheimer, G. 1974. Meereskunde der Ostsee. Springer Verlag, Berlin, 269pp.

Matthäus, W. 1990. Langzeittrends und Veränderungen ozeanologischer Parameter während der gegenwärtigen Stagnationsperiode im Tiefenwasser der zentralen Ostsee. Fischerei-Forschung, 28: 25-34.

Matthäus, W. 2001. Hydrographisch-chemische Zustandseinschätzung der Ostsee 1999. Available online at http://www.io-warnemuende.de/ research/de zustand.html.

Moodley, L., Troelstra, S.R. \& vanWeering, C.E. 1993. Benthic foraminiferal response to environmental change in the Skagerrak, northeastern North Sea. Sarsia, 78: 129-139.

Murray, J.W. 1973. Distribution and ecology of benthic foraminiferids. Heinemann Educational Books, London, 274pp.

Murray, J.W. 2000. When does environmental variability become environmental change? The proxy record of benthic foraminifera. In: Martin, R.E. (Ed.), Environmental micropaleontology. The application of microfossils to environmental geology. Kluwer, New York, 7-37.

Murray, J.W. 2001. The niche of benthic foraminifera, critical thresholds and proxies. Marine Micropaleontology, 41: 1-7.

Murray, J.W. \& Bowser, S.E. 2000. Mortality, protoplasm decay rate, and reliability of staining techniques to recognize 'living' foraminifera: a review. Journal of Foraminiferal Research, 30: 66-70.

Nausch, G., Matthäus, W. \& Feistel, R. 2003. Hydrographical and hydrochemical conditions in the Gotland Deep area between 1992 and 2003. Oceanologia, 45: 557-569.

Nausch, G., Feistel, R., Lass, H.U., Nagel, K. \& Siegel, H. 2004. Hydrographisch-chemische Zustandseinschätzung der Ostsee 2003. Meereswissenschaftliche Berichte/Marine Science Reports, 59; $1-79$.

Nausch, G., Feistel, R., Lass, H.U., Nagel, K. \& Siegel, H. 2005. Hydrographisch-chemische Zustandseinschätzung der Ostsee 2004. Meereswissenschaftliche Berichte/Marine Science Reports, 62: 1-78.

Nehring, D. 1991. Recent nutrient trends in the western and central Baltic Sea, 1958-1989. Acta Ichthyologia et Piscatoria, 21: 152-162.

Nordberg, K., Filipsson, H.L., Gustafsson, M., Harland, R. \& Roos, P. 2001. Climate, hydrographic variations and marine benthic hypoxia in Koljö Fjord, Sweden. Journal of Sea Research, 46: 187-200.

Nürnberg, D., Brughmans, N., Schönfeld, J., Ninnemann, U. \& Dullo, W.-Chr. 2004. Paleo-export productivity, terrigenous flux, and sea surface temperature around Tasmania - Implications for glacial/ interglacial changes in the Subtropical Convergence Zone. Geophysical Monograph Series, 151: 291-318.

Olsson, I. 1976. Distribution and ecology of the foraminiferan Ammotium cassis (Parker) and its ecological significance. Zoon, 4: 137-147.

Principato, S.M., Jennings, A.E., Kristjansdottir, G.B. \& Andrews, J.T. 2005. Andrews Glacial-Marine or Subglacial Origin of Diamicton Units from the Southwest and North Iceland Shelf: Implications for the Glacial History of Iceland. Journal of Sedimentary Research, 75: 968-983.

Rheinheimer, G. 1996. Meereskunde der Ostsee. Springer Verlag, Berlin, $338 \mathrm{pp}$.

Rhumbler, L. 1935. Rhizopoden der Kieler Bucht, gesammelt durch A. REMANE, I. Teil. Schriften des Naturwissenschaftlichen Vereins Schleswig-Holstein, 21: 143-194.

Rottgardt, D. 1952. Mikropaläontolgische wichtige Bestandteile rezenter brackischer Sedimente an den Küsten Schlewig-Holsteins. Meyniana, 1: 169-228.

Seidenkrantz, M.-S. 1993. Subrecent changes in the foraminiferal distribution in the Kattegat and the Skagerrak, Scandinavia: anthropogenic influence and natural causes. Boreas, 22: 383-395. 
Van Voorthuysen, J.H. 1960. Die Foraminiferen des DollartEms-Estuarium. Verhandelingen van het Koninklijk Geologisch Mijnbouwkundig Genootschap, 19: 237-269.

Wassmann, P. 1990. Calculating the load of organic carbon to the aphotic zone in eutrophicated coastal waters. Marine Pollution Bulletin, 21: 183-187.

Wefer, G. 1976. Umwelt, Produktion und Sedimentation benthischer Foraminiferen in der westlichen Ostsee. Reports Sonderforschungsbereich 95 Wechselwirkung Meer - Meeresboden, 14: 1-103.
Wefer, G. \& Lutze, G.-F. 1978. Carbonate production by benthic foraminifera and accumulation in the western Baltic. Limnology and Oceanography, 23: 992-996.

Wüst, G. \& Brockmus, W. 1955. Ozeanographische Ergebnisse einer Untersuchungsfahrt mit Forschungskutter 'Südfall' durch die Ostsee Juni/Juli 1954 (anlässlich der totalen Sonnenfinsternis auf Öland). Kieler Meeresforschungen, 11: 3-21. 